\title{
A psoriasis és az oxidatív stressz
}

\author{
Péter Iván dr. ${ }^{1}$ - Jagicza Anna dr. ${ }^{1}$ - Ajtay Zénó dr. ${ }^{1,3}$ \\ Kiss István dr. ${ }^{2}$. Németh Balázs dr. ${ }^{1,2}$ \\ ${ }^{1}$ Zsigmondy Vilmos Harkányi Gyógyfürdőkórház, Harkány \\ ${ }^{2}$ Pécsi Tudományegyetem, Általános Orvostudományi Kar, Orvosi Népegészségtani Intézet, Pécs \\ ${ }^{3}$ Pécsi Tudományegyetem, Klinikai Központ, Szívgyógyászati Klinika, Pécs
}

A jelen tudományos közleményt a szerzők a Pécsi Tudományegyetem alapitásának 650. évfordulója emlékének szentelik.

\begin{abstract}
A psoriasis hazánkban és világviszonylatban is a leggyakrabban előforduló bőrbetegségek egyike. Jelentőségét hangsúlyozza a gyakran élethossziglan fennálló plakkok okozta fájdalom, mozgáskorlátozottság és a pszichés terhelés életminőségre gyakorolt hatása. Szövődményeit tekintve a nemegyszer maradandó károsodásokat okozó arthritis psoriaticán túl, a psoriasisos betegek esetében nagyobb cardiovascularis kockázattal kell számolni, gyakrabban alakulnak ki gyulladásos bélbetegségek és bizonyos daganatok. Az exogén és endogén tényezők okozta oxidatív stressz és a genetikai prediszpozíció hozzájárulhat a keratinocyták hiperproliferációjához és abnormális differenciálódásához, ezáltal a psoriasis kialakulásához, illetve fenntartásához. A nagyfokú oxidatív stressz felelős lehet továbbá a psoriasis szövődményeinek megjelenéséért. Jelen közleményben, rövid patofiziológiai áttekintés után, néhány jól ismert biomarker (aszimmetrikus dimetilarginin, malonilaldehid, szuperoxid dizmutáz, kataláz) segítségével a szerzók bemutatják az oxidatív stressz szerepét a psoriasis és szövődményeinek kialakulásában. Orv. Hetil., 2016, 157(45), 1781-1785.
\end{abstract}

Kulcsszavak: psoriasis, biomarker, oxidatív stressz

\section{Psoriasis and oxidative stress}

Psoriasis is among the most common dermatological diseases worldwide. Its significance is emphasized by adverse effects on quality of life, caused by chronic pain, physical and psychical disability due to psoriatic plaques. Besides the development of psoriatic arthritis, which often causes permanent joint damage, former studies revealed an increased risk of inflammatory bowel disease, cardiovascular disease and certain types of cancer. Genetic predisposition and oxidative stress caused by exogenous and endogenous factors can contribute to abnormal differentiation and hyperproliferation of keratinocytes, accordingly the development and maintenance of psoriasis. Moreover, excessive oxidative stress can be responsible for the onset of psoriasis complications. After a brief pathophysiological summary the authors discuss the role of oxidative stress in the development of psoriasis and its complications through several well studied biomarkers (asymmetric dimethylarginine, malondialdehyde, superoxide dismutase, catalase).

Keywords: psoriasis, biomarker, oxidative stress

Péter, I., Jagicza, A., Ajtay, Z., Kiss, I., Németh, B. [Psoriasis and oxidative stress]. Orv. Hetil., 2016, 157(45), $1781-1785$.

(Beérkezett: 2016. augusztus 3.; elfogadva: 2016. augusztus 24.)

\section{Rövidítések}

ADMA = aszimmetrikus dimetilarginin; $\mathrm{BB}=$ béta-blokkoló; $\mathrm{BMI}=$ body mass index; CARD-14 = caspase recruitment domain family member 14 , CAT = catalase; $\mathrm{CV}=$ cardiovascularis; DLQI = Dermatology Life Quality Index, IF = interferon; $\mathrm{IL} 12 \mathrm{~B}=$ interleukin $12 \mathrm{~B} ; \mathrm{MDA}=$ malonilaldehid; $\mathrm{MHC}=$ major histocompatibility complex; $\mathrm{Li}=$ lítium; $\mathrm{MI}=$ myocar dialis infarctus; $\mathrm{NF} \kappa \mathrm{B}=$ nuclear factor kappa BVZ; NSAID = nem szteroid gyulladáscsökkentő; PASI = Psoriasis Area Seve- rity Index; PSORS = psoriasis-susceptibility; PsA = arthritis psoriatica; $\mathrm{SOD}=$ szuperoxid dizmutáz; $\mathrm{TNF}=$ tumor necrosis factor

A psoriasis a leggyakrabban előforduló bőrbetegségek egyike. Prevalenciája Európában 0,7-2,9\% közé tehető. Epidemiológiáját tekintve az Egyenlítőtől távolodva 
egyre gyakrabban fordul elő. Nemi megoszlása közel azonos, felnőttekben gyakrabban jelentkezik, mint gyermekekben. Előfordulási gyakorisága 60 éves korig folyamatosan növekvő, majd csökkenő tendenciát mutat [1]. Bár számos tényezőt azonosítottak, amely szerepet játszhat a psoriasis kialakulásában, a pontos okok ez idáig ismeretlenek. A betegség diagnózisa napjainkban is panaszok és tünetek alapján történik. Jelenlegi ismereteink szerint a psoriasist meggyógyítani nem lehet, a terápiás cél a tünetmentesség elérése és a szövődmények elkerülése. Irodalmi adatok szerint a psoriasis kiterjedéstől és súlyosságtól függően a pszichés terheltség, a fájdalom, valamint az önellátó képesség csökkenése révén erősen befolyásolja az életminőséget, szociális konfliktusok kialakulásához vezethet [2]. A psoriasisos betegek esetében nagyobb CV-rizikóval kell számolnunk, hiszen gyakrabban és fiatalabb életkorban alakul ki a diabetes, az elhízás és a hypertonia. Továbbá az egészséges populációhoz viszonyítva a Crohn-betegség elófordulási gyakorisága csaknem 4-szeres, míg a colitis ulcerosa 7,5-szer gyakrabban fordul elő psoriasisos betegekben. Utánkövetéses vizsgálatok szerint a psoriasisos betegek esetében a CV-rizikó emelkedésén túl bizonyos daganatok (tüdő, gyomor és nyelőcső, máj, pancreas) is gyakrabban alakulnak ki [3]. Emiatt fontos és kiemelt terület a psoriasis korai diagnózisát segítő markerek keresése és klinikai hasznosságának vizsgálata, különös tekintettel az oxidatív stresszre, amely a fenti betegségek mindegyikében kulcsfontosságú tényező. Jelen közleményben rövid patofiziológiai áttekintés után összefoglaljuk az oxidatív stressz szerepét a psoriasis és szövődményeinek kialakulásában.

\section{A psoriasis patofiziológiája}

A psoriasisos betegek közel 40\%-ában találunk pozitív családi anamnézist az elsőfokú rokonok között [4]. Ikeriker vizsgálatok szerint a monozigóta ikrek esetében, amennyiben az egyik iker psoriasisban szenved, a másik ikerben 70\%-os valószínűséggel jelenik meg a betegség. Ezzel szemben a dizigóták esetében ez mindössze 20\% [5]. Genetikai vizsgálatok számos faktort azonosítottak, amelyek szerepet játszhatnak a psoriasis kialakulásában. E gének döntő többsége az immunrendszer múködésében játszik szerepet. A psoriasis kialakulásával összefüggő legnagyobb jelentőségű genetikai faktor a 6-os kromoszómán található PSORS-locusok. A PSORS-locusok által kódolt gének (például: HLA-C, HLA-Cw6) szerepet játszanak a szerzett immunitás kialakításában, legfőképpen a saját és idegen molekulák, illetve antigének felismerésében. Irodalmi adatok szerint a PSORSlocusok tehetők felelőssé a manifeszt psoriasisok csaknem 50\%-áért. Tekintve, hogy az immunrendszer kulcsfontosságú alkotóelemének funkcióját befolyásolja, nem meglepő, hogy a psoriasison túl összefüggést találtak a gyulladásos bélbetegségek, az atopiás dermatitis, a sclerosis multiplex és a PSORS-locus mutációi között [3]. A PSORS-locusokon túl bizonyos interleukin gének túlexpressziója, a T-sejtek mediálta immunválasz facilitációja révén szintén hozzájárul a psoriasis kialakulásához. Ezen interleukinek közül kiemelt jelentőségű az IL-12 és az IL-23, amelyeknek túlzott expresszióját a psoriasisos plakkokban is kimutatták. Továbbá összefüggést találtak a PsA és a fent említett interleukinek fokozott expressziója között. Az IL-12 és IL-23 psoriasisban betöltött szerepét tovább hangsúlyozza az ezen IL-ek ellen kifejlesztett monoklonális antitestekkel elért látványos javulás, amely psoriasis és a PsA esetében is kiemelkedő volt [6]. Az apoptózis és a sejtdifferenciáció fó regulátorai közül az NFkB fontos szerepet tölt be a psoriasis kialakulásában és progressziójában. $\mathrm{Az} \quad \mathrm{NF} k \mathrm{~B}$ nukleáris expressziója hatással van a keratinocyták differenciációjára, a T-sejtek aktivitására és a dendritikus sejtek osztódására. Psoriasisos betegek esetében az NFkB egyrészt aktiválja a T- és B-sejtek antigénkötő receptorait, másrészt elősegíti az IL-12 termelődését, ezáltal fenntartja a kialakult autoimmun gyulladásos folyamatot [7]. A nemrég azonosított CARD-14-jelátvitelt szabályozó protein hibás múködése összekötő kapocs lehet a fent említett PSORS-locus és az NFkB között. Harden és $m$ tsai psoriasisos betegekben immunfluoreszcens festéssel nemcsak a keratinocytákban, hanem az endothelsejtekben is CARD-14-pozitivitást találtak. A CARD-14 protein többek között felelős az $\mathrm{NF}_{\kappa} \mathrm{B}$ aktivitásának regulációjáért, így közvetett markere lehet az NFฬB aktivitásának. A psoriasisos beteg endothelsejtjein kimutatott CARD-14-pozitivitás összefüggésben lehet a szisztémás gyulladás kialakulásával, továbbá a cardiovascularis komorbiditások megjelenésével [8].

A psoriasis kialakulásához a genetikai faktorokon túl számos környezeti tényező is hozzájárul. Irodalmi adatok szerint bizonyos fizikai (sérülések, hegek, nyomáspontok), kémiai behatások (irritáló és toxikus anyagok) után, illetve egyes infekciókat (Streptococcus pyogenes, hepatitiszvírus, varicella-zoster vírus) követően gyakrabban alakul ki psoriasis [9-12]. A fentieken kívül a klasszikus rizikófaktorokkal (alkoholfogyasztás, dohányzás, elhízás) rendelkező betegek esetében is nagyobb a psoriasis incidenciája. A túlzott alkoholfogyasztás és a dohányzás által okozott oxidatív stressz és immunmoduláció krónikus gyulladáshoz vezet, amely a psoriasis kiváltója és fenntartója lehet $[13,14]$. Egy több mint 130 ezer beteget involváló összefoglaló közlemény szerint pozitív összefüggés van a BMI és a psoriasis súlyossága között. A zsírszövet által termelt proinflammatorikus adipocytokinek (IL-1, IL-6, TNF- $\alpha$ ) immunmoduláló hatásukkal szintén hozzájárulnak a psoriasis kialakulásához [15].

Összefoglalva elmondható, hogy a psoriasis az immunrendszer egyes komponenseinek egy olyan genetikailag kódolt hibája, amely bizonyos noxák hatására manifeszt betegséggé alakul. 


\section{A psoriasis diagnózisa és kezelése}

A psoriasis diagnózisa a klinikai tünetek alapján történik, amelyek közül a leggyakoribbak a hámló erythemás plakkok, ezek lehetnek fájdalmasak vagy viszketőek. Az esetek döntő többségében a fizikális vizsgálat elegendő a diagnózis kimondásához, bizonytalan esetekben bőrbiopszia végzendő [3]. A psoriasis súlyosságának objektív tüneteken alapuló számszerúsítésére leggyakrabban a PASI-score-t használják, míg a betegség életminőségre gyakorolt szubjektív hatásának felmérésére a DLQI kérdőív használatos [16]. A psoriasis terápiájában alkalmazhatunk lokálisan (például szteroid-, ditranoltartalmú kenőcsök), illetve szisztémásan ható szereket (például methotrexat, ciclosporin, fumarat, D-vitamin, A-vitamin, biológiai terápia). A gyógyszereken túl a balneo- és fototerápia bizonyos betegek esetében igen jó hatásfokú a psoriasis kezelésében. Irodalmi adatok szerint a psoriasis kezelésének leghatékonyabb módja a fenti kezelések valamely kombinációban történő alkalmazása, természetesen minden esetben személyre szabott, tervezett módon [17].

\section{Oxidatívstressz-markerek a psoriasisban}

Tekintve, hogy a psoriasis élethossziglan fennálló betegség, amelyet jelenleg teljes mértékben meggyógyítani nem lehet, szükségessé vált olyan biomarkerek keresése, amelyek képesek a betegség, illetve a szövődmények kialakulását előre jelezni. A jelenleg ismert biomarkerek jelentős része az 1 ábrán szemléltetett nem genetikai tényezők jelenlétét, illetve „károsító hatásuk” mértékét jelzi.

\section{A NO-rendszer és a psoriasis}

Az oxidatív stressz a psoriasis iniciációjában és progreszsziójában szerepet játszó tényező. Molekuláris biológiai és immunhisztokémiai vizsgálatok szerint mind a keratinocyták, mind a fibroblastok expresszálják az L-argininból NO-ot szintetizáló NOS enzimet. A képződött NO fontos szerepet játszik a kültakaró külső hatásokra (infekció, UV-sugárzás, hő) adott válaszreakcióinak szabályozásában [18]. Psoriasisos betegekben a NOS fokozott expressziója miatt ugyanakkor a NO mellett jelentős mennyiségú peroxinitrit-szabadgyök is felszabadul. A szabadgyökökról általánosságban elmondható, hogy nagy reaktivitású, rövid élettartamú anyagok lévén, amennyiben utánpótlásuk folyamatos, súlyos károsodásokat képesek okozni a proteinekben, sejtmembránokban, sőt a DNS-ben is. Irodalmi adatok szerint a psoriasisos betegekben a peroxinitrit koncentrációja szignifikánsan magasabb, mint az egészséges kontrollokban. Lényeges továbbá, hogy a peroxinitrit mennyisége a psoriasis súlyosságával egyenesen arányos [19]. A NOrendszer szabályozásában kulcsfontosságú szerepet játszik az ADMA, amely a NOS endogén kompetitív inhibitora, az endotheldiszfunkció markere. Koncentrációja emelkedett a klasszikus rizikófaktorokkal rendelkező betegekben. Számos szerző talált összefüggést az oxidatív

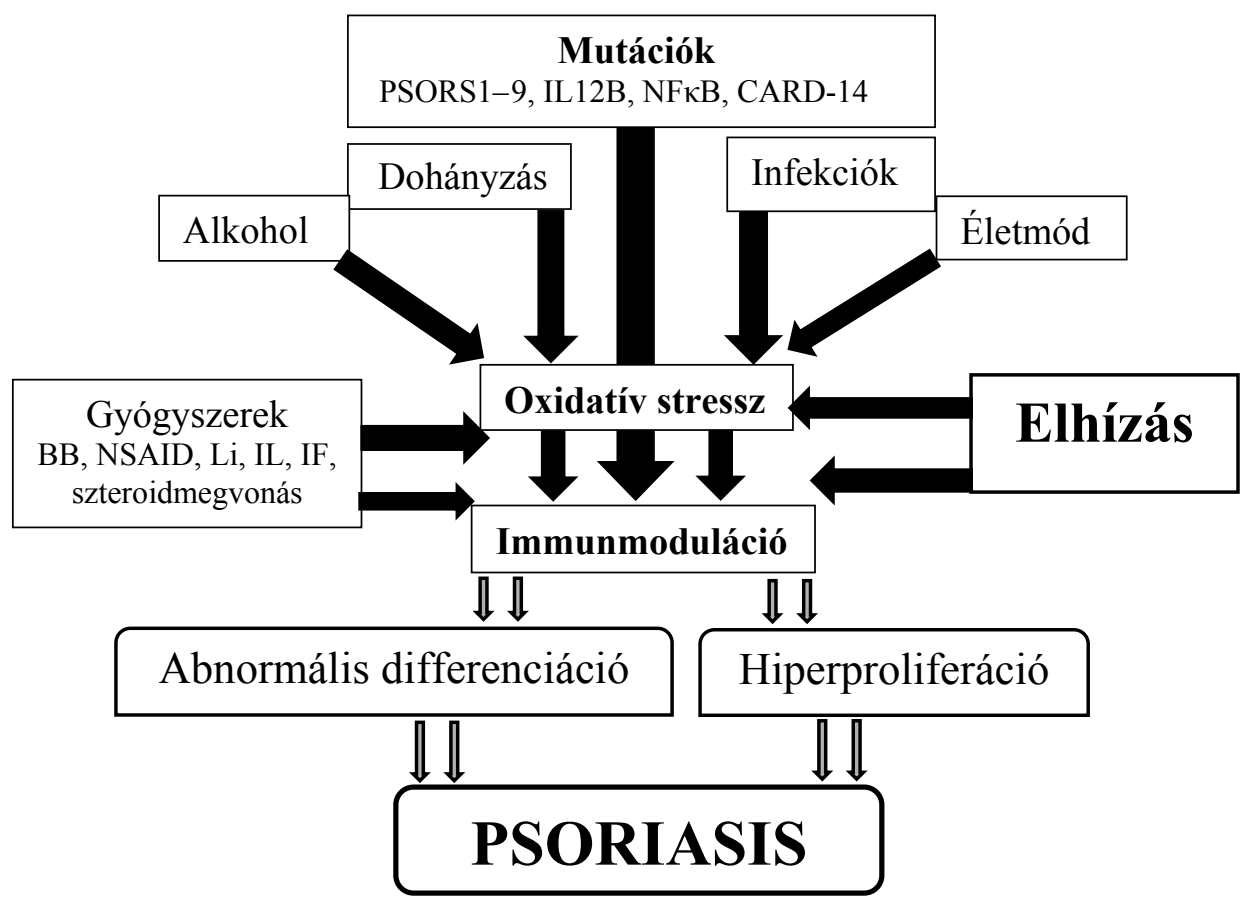

1. ábra

A psoriasis rizikófaktorai és kialakulásának legfőbb lépései

$\mathrm{BB}=$ béta-blokkoló; $\mathrm{CARD}-14$ = caspase recruitment domain family member $14 ; \mathrm{IF}=$ interferon; IL12B = interleukin $12 \mathrm{~B} ; \mathrm{Li}=$ lítium; $\mathrm{NF} \kappa \mathrm{B}=$ nuclear factor kappa B; NSAID = nem szteroid gyulladáscsökkentő; PSORS = psoriasis-susceptibility 
stressz mértéke és az ADMA koncentrációja között. Ezenkívül az L-arginin/ADMA arány használható a NO biológiai hozzáférhetőségének megítélésére [20]. Bilgiç és mtsai szisztémás kezelésben nem részesülő, legalább 6 hónapja tünetes psoriasisos betegek és egészséges kontrollok ADMA- és L-arginin-koncentrációját hasonlították össze. A psoriasisban szenvedő betegek ADMA-koncentrációja a kontrollcsoporthoz képest szignifikánsan magasabb, míg az L-arginin/ADMA aránya szignifikánsan alacsonyabb volt. Továbbá pozitív összefüggést találtak az ADMA-koncentráció és a PASI között [21]. Miller és mtsai által készített metaanalízis szerint a psoriasisos betegek között szignifikánsan gyakrabban jelennek meg a cardiovascularis rizikófaktorok, az MI és alakul ki az ischaemiás szívbetegség [22]. A témában készült publikációk áttekintése után a Richard és mtsai által készített szakmai állásfoglalás a fiatal, súlyos psoriasisban szenvedőket az MI kialakulásának szempontjából emelkedett rizikójúnak minősítette (B szintű evidencia) [23]. Ezek az eredmények megerősítik azt a feltételezést, miszerint a NO-rendszer fontos szerepet játszik a psoriasis patofiziológiájában és a CV-szövődmények kialakulásában.

\section{Hyperhomocysteinaemia és a psoriasis}

A hyperhomocysteinaemia az ISZB és a stroke független rizikófaktora [24]. Brazzelli és mtsai egészségesekhez képest szignifikánsan magasabb plazmahomociszteinkoncentrációt mértek a psoriasisos betegekben [25]. A homocisztein reaktívszulfhidril-csoportja fiziológiás pH-n $\mathrm{O}_{2}$ jelenlétében könnyedén oxidálódik, reaktív szabadgyökké alakul [26]. A szabadgyökök károsító hatása mellett a magas plazmahomocisztein-koncentráció hozzájárul az endotheldiszfunkció kialakulásához, és a psoriasisban jellemző krónikus gyulladás fenntartásához. Továbbá csökkenti az erek rugalmasságát és növeli a thrombosiskészséget, ezáltal növeli a psoriasisos betegek CV-rizikóját. Egy több mint 7000, psoriasisban szenvedő beteget vizsgáló retrospektív tanulmány szerint a methotrexattal és folsavval kezelt betegek körében alacsonyabb volt a vascularis betegségek incidenciája. Ennek hátterében a methotrexat és a folsav gyulladáscsökkentő és gyökfogó hatása valószínúsíthető, amely tovább erősíti azt a feltételezést, miszerint a psoriasisos betegek emelkedett CV-rizikójáért többek között az oxidatív stressz és a krónikus gyulladás tehető felelőssé [24].

\section{Malonilaldehid és a psoriasis}

Az MDA az oxidatív stressz jól ismert biomarkere. A szabadgyökök lipidekkel történő reakciója következtében lipidperoxidáció jön létre, amelynek végterméke az MDA. Az MDA mennyisége az oxidatív stressz hatására nő, így változásából közvetett módon következtetni lehet az oxidatív stressz mértékére. Több tanulmány ki- mutatta, hogy egészséges kontrollokhoz viszonyítva mind a szimptómás, mind a nyugvó psoriasisban szenvedő betegekben szignifikánsan magasabb az MDA koncentrációja. Az emelkedett plazma- és szérum-MDAkoncentrációkon túl a bőrbiopsziával nyert minták esetében az aktív plakkokban szignifikánsan magasabb MDA-koncentrációt találtak. Mindezek hátterében a psoriasisos plakkokban már a betegség korai fázisában jelen lévő polimorfonukleáris fehérvérsejtek szabadgyökterhelést okozó hatása állhat. Ezt a feltételezést erősíti az az eredmény, miszerint pozitív korreláció van a psoriasis súlyossága és az MDA koncentrációja között [19, 2729].

\section{Antioxidáns védőrendszerek müködése psoriasisban}

A bőr a belső (immunmoduláció, dohányzás stb.) és külső tényezők (UV-sugárzás, hő, infekció) hatására folyamatosan ki van téve a szabadgyökök károsító hatásának. Az oxidatív stressz okozta károsodás elleni védelem legfontosabb enzimei a SOD és a CAT. Kadam és mtsai újonnan diagnosztizált psoriasisos betegek és egészséges kontrollok SOD és CAT enzimaktivitását hasonlították össze. A psoriasisos betegekben a kontrollcsoporthoz viszonyítva mindkét antioxidáns enzim aktivitása szignifikáns csökkenést mutatott. Ezen vizsgálat arra enged következtetni, hogy a psoriasis kialakulása előtt is exceszszív az oxidatív stressz mértéke, amely meghaladja a rendelkezésre álló védőmechanizmusok semlegesítő kapacitását. Továbbá, a csökkent SOD-aktivitás tovább erősítheti az epidermalis hiperproliferációt, ezáltal hozzájárulhat a psoriasis fenntartásához [19].

\section{Következtetések}

A fentiek alapján elmondható, hogy bár a psoriasis kialakulásának egyértelmű oka nem teljesen tisztázott, az utóbbi években számos genetikai és környezeti tényezőt azonosítottak, amelyek szerepet játszhatnak a betegség kialakulásában. Ezek közül kulcsfontosságú lehet a megnövekedett oxidatív stressz, amelynek monitorozása oxidatívstressz-markerek segítségével valósítható meg. Ilyen, a klinikai gyakorlatban is hasznosítható biomarker lehet az MDA, amelynek meghatározásával megbízhatóan és viszonylag egyszerü módon tájékozódhatunk az oxidatív stressz mértékéról. Továbbá bizonyos betegekben hasznos lehet az ADMA koncentrációjának meghatározása, amely tájékoztatást ad a NO-rendszer állapotáról és a CV-rizikóról. Ezáltal alkalmas lehet az egyénre szabott kezelés hatékonyságának megítélésére, valamint a magas rizikójú betegek kiemelésére.

Az oxidatív stressz monitorozása psoriasisos betegekben segíthet a korai diagnózis meghozásában, a szövődmények előrejelzésében és a terápia hatásosságának megítélésében. 
Anyagi támogatás: A közlemény megírása, illetve a kapcsolódó kutatómunka anyagi támogatásban nem részesült.

Szerzői munkamegosztás: N. B., J. A.: Irodalomkutatás, a kézirat megszövegezésének, szerkesztésének előkészítése. N. B., P. I.: Irodalomkutatás, a kézirat végső megszövegezése, végső szerkesztés elvégzése, ábrakészítés. K. I., A. Z., N. B.: A téma megválasztása, a kézirat szakmai véleményezése. A cikk végleges változatát valamenynyi szerző elolvasta és jóváhagyta.

Érdekeltségek: A szerzőknek nincsenek érdekeltségeik.

\section{Irodalom}

[1] Parisi, R., Symmons, D. P., Griffiths, C. E., et al.: Global epidemiology of psoriasis: a systematic review of incidence and prevalence. J. Invest. Dermatol., 2013, 133(2), 377-385.

[2] Griffiths, C. E., Barker, J. N.: Pathogenesis and clinical features of psoriasis. Lancet, 2007, 370(9583), 263-271.

[3] Smith, C. H., Barker, J. N.: Psoriasis and its management. BMJ, 2006, 333(7564), 380-384.

[4] Gladman, D. D., Anborn, K. A., Schachter, R. K., et al.: HLA antigens in psoriatic arthritis. J. Rheumatol., 1986, 13(3), 586592.

[5] Krueger, G., Ellis, C. N.: Psoriasis - recent advances in understanding its pathogenesis and treatment. J. Am. Acad. Dermatol., 2005, 53(1 Suppl. 1), S94-S100.

[6] Johnsson, H. J., McInnes, I. B.: Interleukin-12 and interleukin-23 inhibition in psoriatic arthritis. Clin. Exp. Rheumatol., 2015, 33(5 Suppl. 93), S115-S118.

[7] Bakry, O. A., Samaka, R. M., Shoeib, M. A., et al.: Nuclear factor kappa $\mathrm{B}$ and cyclo-oxygenase-2: two concordant players in psoriasis pathogenesis. Ultrastruct. Pathol., 2015, 39(1), 49-61.

[8] Harden, J. L., Lewis, S. M., Pierson, K. C., et al.: CARDl4 expression in dermal endothelial cells in psoriasis. PLoS ONE, 2014, 9(11), ell1255.

[9] Poikolainen, K., Reunala, T., Karvonen, J., et al.: Alcohol intake: a risk factor for psoriasis in young and middle aged men? BMJ, 1990, 300(6727), 780-783.

[10] Islam, M. T., Paul, H. K., Zakaria, S. M., et al.: Epidemiological determinants of psoriasis. Mymensingh Med. J., 2011, 20(1), 9-15

[11] Weigl, B. A.: The significance of stress hormones (glucocorticoids, catecholamines) for eruptions and spontaneous remission phases in psoriasis. Int. J. Dermatol., 2000, 39(9), 678-688

[12] Halawani, M. R.: Dermatological manifestations of hepatitis $\mathrm{C}$ virus infection in Saudi Arabia. Saudi Med. J., 2014, 35(6), 531537.

[13] Naldi, L.: Epidemiology of psoriasis. Curr. Drug Targets Inflamm. Allergy, 2004, 3(2), 121-128.

[14] Farkas, A., Kemény, L.: Psoriasis and alcohol: is cutaneous ethanol one of the missing links? Br. J. Dermatol., 2010, 162(4), $711-716$.
[15] Fleming, P., Kraft, J., Gulliver, W. P., et al.: The relationship of obesity with the severity of psoriasis: a systematic review. J. Cutan. Med. Surg., 2015, 19(5), 450-456.

[16] Mrowietz, U., Kragballe, K., Reich, K., et al.: Definition of treatment goals for moderate to severe psoriasis: a European consensus. Arch. Dermatol. Res., 2011, 303(1), 1-10.

[17] Bailey, E. E., Ference, E. H., Alikhan, A., et al.: Combination treatments for psoriasis: a systematic review and meta-analysis. Arch. Dermatol., 2012, 148(4), 511-522.

[18] Cals-Grierson, M. M., Ormerod, A. D.: Nitric oxide functions in the skin. Nitric Oxide, 2004, 10(4), 179-193.

[19] Kadam, D. P., Suryakar, A. N., Ankush, R. D., et al.: Role of oxidative stress in various stages of psoriasis. Indian J. Clin. Biochem., 2010, 25(4), 388-392.

[20] Németh, B., Kustán, P., Németh, Á., et al.: Asymmetric dimethylarginine: predictor of cardiovascular diseases? [Aszimmetrikus dimetilarginin: a cardiovascularis betegségek prediktora?] Orv. Hetil., 2016, 157(13), 483-487. [Hungarian]

[21] Bilgiç, Ö., Altmyazar, H. C., Baran, H., et al.: Serum homocysteine, asymmetric dimethyl arginine (ADMA) and other arginineNO pathway metabolite levels in patients with psoriasis. Arch. Dermatol. Res., 2015, 307(5), 439-444.

[22] Miller, I. M., Ellervik, C., Yazdanyar, S., et al.: Meta-analysis of psoriasis, cardiovascular disease, and associated risk factors. J. Am. Acad. Dermatol., 2013, 69(6), 1014-1024.

[23] Richard, M. A., Barnetche, T., Horreau, C., et al.: Psoriasis, cardiovascular events, cancer risk and alcohol use: evidence-based recommendations based on systematic review and expert opinion. J. Eur. Acad. Dermatol. Venereol., 2013, 27(Suppl. 3), 2-11.

[24] McDonald, I., Connolly, M., Tobin, A. M.: A review of psoriasis, a known risk factor for cardiovascular disease and its impact on folate and homocysteine metabolism. J. Nutr. Metab., 2012, 2012, Article ID 965385.

[25] Brazzelli, V., Grasso, V., Fornara, L., et al.: Homocysteine, vita$\min B_{12}$ and folic acid levels in psoriatic patients and correlation with disease severity. Int. J. Immunopathol. Pharmacol., 2010, 23(3), 911-916

[26] Jacobsen, D. W.: Hyperhomocysteinemia and oxidative stress. Arterioscler. Thromb. Vasc. Biol., 2000, 20(5), 1182-1184.

[27] Relhan, V., Gupta, S. K., Dayal, S., et al.: Blood thiols and malondialdehyde levels in psoriasis. J. Dermatol., 2002, 29(7), 399403.

[28] Sikar Aktürk, A., Özdoğan, H. K., Bayramgürler, D., et al.: Nitric oxide and malondialdehyde levels in plasma and tissue of psoriasis patients. J. Eur. Acad. Dermatol. Venereol., 2012, 26(7), 833-837.

[29] Pujari, V. M., Ireddy, S., Itagi, I., et al.: The serum levels of malondialdehyde, vitamin $\mathrm{E}$ and erythrocyte catalase activity in psoriasis patients. J. Clin. Diagn. Res., 2014, 8(11), CCl4CC16. 